\title{
Detection and characterisation of the biopollutant Xenostrobus securis (Lamarck 1819) Asturian population from DNA Barcoding and eBarcoding
}

\author{
Floriaan Devloo-Delva a,1 ${ }^{\text {, Laura Miralles }}{ }^{\mathrm{a}, 1}$, Alba Ardura ${ }^{\mathrm{b}}$, Yaisel J. Borrell ${ }^{\mathrm{a}}$, Ivana Pejovic ${ }^{\mathrm{a}}$, \\ Valentina Tsartsianidou ${ }^{a}$, Eva Garcia-Vazquez ${ }^{\mathrm{a}, *}$ \\ a Department of Functional Biology, University of Oviedo, C/ Julián Clavería s/n, 33006 Oviedo, Spain \\ b USR3278-CRIOBE-CNRS-EPHE. Laboratoire d'excellence "CORAIL". Université de Perpignan-CBETM. 58 Rue Paul Alduy. 66860-Perpignan, CEDEX. France
}

\section{A R T I C L E I N F O}

\section{Article history:}

Received 13 January 2016

Received in revised form 1 March 2016

Accepted 4 March 2016

Available online 9 March 2016

\section{Keywords:}

Xenostrobus securis

biological invasion

environmental DNA

Barcoding

phylogenetic expansion signals

Bay of Biscay

\begin{abstract}
A B S T R A C T
DNA efficiently contributes to detect and understand marine invasions. In 2014 the potential biological pollutant pygmy mussel (Xenostrobus securis) was observed for the first time in the Avilés estuary (Asturias, Bay of Biscay). The goal of this study was to assess the stage of invasion, based on demographic and genetic (DNA Barcoding) characteristics, and to develop a molecular tool for surveying the species in environmental DNA. A total of 130 individuals were analysed for the DNA Barcode cytochrome oxidase I gene in order to determine genetic diversity, population structure, expansion trends, and to inferring introduction hits. Reproduction was evidenced by bimodal size distributions of 1597 mussels. High population genetic variation and genetically distinct clades might suggest multiple introductions from several source populations. Finally, species-specific primers were developed within the DNA barcode for PCR amplification from water samples in order to enabling rapid detection of the species in initial expansion stages.
\end{abstract}

(c) 2016 Elsevier Ltd. All rights reserved.

\section{Introduction}

New transport technologies and enhanced spatial connectivity have intensified the process of biological pollution worldwide (Perrings et al., 2002), giving non-indigenous species (NIS) the opportunity to expand and thrive in other regions. A minimum of 1369 NIS have been introduced in Europe (Katsanevakis et al., 2013), and the number is probably underestimated because there are still problems estimating the true identity, global distribution, introduction vectors and population demography of many invasive species (Rilov and Crooks, 2009). DNA helps to reduce taxonomical uncertainties in biota inventories and contributes to identify exotic species, for example molluscs (e.g. McDonald and Koehn (1988); Pejović et al. (2015)), arthropods (Geller et al., 2010) and many other. Many studies have successfully employed DNA for identifying genetic diversity, population structure and putative origin of biological invaders. DNA barcodes such as the cytochrome oxidase subunit I (COI) gene can provide a more detailed description about source populations than historical data (Hoos et al. (2010). Moreover, integrating genetic and non-genetic data can enhance the power of inferring the introduction vector of invasions (Geller et al., 2010). Techniques based on environmental DNA (eDNA) allow to identifying biota directly from water or sediment samples

\footnotetext{
* Corresponding author.

E-mail address: egv@uniovi.es (E. Garcia-Vazquez).

1 These authors contributed equally to this article.
}

(e.g. Harvey et al. (2009); Ardura et al. (2015); Zaiko et al. (2015a, 2015b)). This facilitates rapid detection of potential marine invaders thus enabling a rapid reaction for eradication and control of potential invaders.

Mussels contain several strongly invasive species that are carried as biological pollutants by shipping. The genus Xenostrobus is originally from Australia and New Zealand (Wilson and Hodgkin, 1967, Colgan and da Costa, 2013), where they live in brackish waters. The blackpygmy mussel (Xenostrobus securis) is a biological pollutant that exhibits nowadays a global distribution. Inadvertently transported by ships, it was first observed out of its native range in Japan in 1972 (Kimura et al., 1999). Over the next decades it spread over more regions in South East Asia (Abdel-Razek et al., 1993a, Kohama et al., 2001, Iwasaki, 2006, Morton and Leung, 2015). In Europe it was probably inadvertently introduced with aquaculture imports as well (Giusti et al., 2008). The species arrived in Italy in 1991 (Sabelli and Speranza, 1994) and expanded over the Adriatic Sea (Crocetta, 2011), along the Western Mediterranean: Italy (Lazzari and Rinaldi, 1994, Giusti et al., 2008), South-France and East-Spain (Barbieri et al., 2011). Out of Mediterranean waters, in Europe it was found in Galicia, Northwest Iberia, in 1995 (Garci et al., 2007, Bañón et al., 2008), and in Bay of Biscay in 2010 (Adarraga and Martínez, 2012).

$X$. securis was detected in the central coast of Spanish Bay of Biscay for the first time in 2014 (Pejović et al., 2015), at low density and inside one port. It was therefore expected that these specimens were part of a recent introduction event, with low genetic population variation due to 
founder effects. The present work follows that discovery. Ecological and DNA barcoding were carried out to assess population status, detect (if any) signs of population expansion, and develop a Barcode-based tool for easy detection of the species from water samples (environmental DNA approach).

\section{Methods}

\subsection{The species}

Xenostrobus securis exhibits a salinity range from 2 to 31 PSU and can withstand temperatures from $1{ }^{\circ} \mathrm{C}$ (Iwasaki and Yamamoto, 2014) to $33{ }^{\circ} \mathrm{C}$ (Kimura and Sekiguchi, 2009). During periods of extreme salinities it can close the valves and survive without feeding up to four months (Wilson, 1968). Larvae have a planktonic phase that lasts for approximately two months (Abdel-Razek et al., 1993b). With a maximum lifespan of two years and an average size between 20 and $30 \mathrm{~mm}$ (maximum $47 \mathrm{~mm}$ ) individuals can mature within their first year of survival (Wilson, 1969), generally starting from $10 \mathrm{~mm}$ or even smaller (Abdel-Razek et al., 1993b) and occupy different niches with its capability for adhesion to different substrates (Babarro and Lassudrie, 2011).

\subsection{Study area and survey protocol}

Avilés $\left(43^{\circ} 34^{\prime} 07^{\prime \prime} \mathrm{N}, 5^{\circ} 55^{\prime} 20^{\prime \prime} \mathrm{W}\right)$ is a major port of Asturias located within Avilés Estuary (Flor et al., 2006). Every year it receives around 800 commercial, 200 recreational and 40 fishing vessels (Autoridad Portuaria de Avilés, 2014). The estuary contains considerable industrial and infrastructural development (coking and steel plants, between others).

For surveying X. securis in the Avilés Estuary in January 2015, the sampling protocol was adapted from the Bernice P. Bishop Museum (BPBM) protocols (Bishop and Hutchings, 2011). Seven places (AV01 to AV07) with three random replicates from each one were chosen within the estuary. The site AV02 is the site where the species was found in 2014 by Pejovic et al. (2015). All the mussels within a $100 \mathrm{~cm}^{2}$ quadrat were collected, measured, counted and stored in absolute ethanol. Morphometric features (maximum length, width and height) were obtained with a Vernier calliper (error $\pm 1 \mathrm{~mm}$ ).

\subsection{Individual DNA Barcoding}

From each site 15-25X. securis individuals were randomly picked for DNA Barcoding. DNA was extracted from the adductor muscle $\left( \pm 3 \mathrm{~mm}^{3}\right)$ with Chelex method (Estoup et al., 1996). The Barcode COI gene was PCR amplified with universal primers (Geller et al., 2013) in a Veriti Blue Thermal Cycler, Applied Biosystems following the protocol described by Geller et al. (2013). PCR products were examined on a $2 \%$ agarose gel stained with SimplySafe ${ }^{\mathrm{TM}}$. PCR products were sent to Macrogen (Amsterdam, The Netherlands) for sequencing in ABI3730xl DNA sequencer (Applied Biosystems).

DNA Barcoding was also applied to other molluscs present in site AV07 employing the same methodology.

\subsection{Development of Xenostrobus securis specific eBarcoding}

\subsubsection{In silico design of species-specific primers}

For designing species-specific primers for Xenostrobus securis we followed the approach described by Ardura et al. (2015) for Rangia cuneata but using the cytochrome oxidase I (COI) gene as a DNA Barcode instead of $16 \mathrm{~S}$ rDNA. Briefly, COI gene sequences of a wide taxonomic range of mollusks were downloaded from public databases: GenBank (http://www.ncbi.nlm.nih.gov/genbank/) and BOLD (http://www. boldsystems.org/). They were aligned using ClustalW (Thompson et al., 1994) application on BioEdit. Species-specific primers were developed within the COI region after aligning all the $X$. securis sequences retrieved from the databases, those generated in the present study, and a set of sequences from closely related bivalves; then a region with maximum identity with the target species and minimum with the rest was visually selected. Primer characteristics were checked with the IDT SciTools Oligo Analyzer v3.0. (Coralville, USA). For in silico validation of the new primers, GenBank database was searched for highly similar sequences (MEGABLAST) with parameters adjusted for short input sequences, to confirm the primers only hybridize with $X$. securis sequences.

\subsubsection{Marker validation with fresh tissue}

The primers were first assayed in DNA extracted from fresh tissue of $X$. securis as explained above (see Section 2.3). PCRs were conducted on Veriti Blue Thermal Cycler. For a final volume of $20 \mu \mathrm{l} 1 \times$ Taq buffer, $1.5 \mathrm{mM} \mathrm{MgCl} 2,0.25 \mathrm{mM}$ dNTPs, $1 \mu \mathrm{M}$ of each primer, $200 \mathrm{ng} / \mu \mathrm{l}$ Bovine Serum Albumin (BSA), $0.0325 \mathrm{U} / \mu \mathrm{l}$ Taq polymerase (Promega) and $4 \mu \mathrm{l}$ of target DNA ( $\pm 50 \mathrm{ng}$ ) were used. Conditions were set to an initial denaturation at $95^{\circ} \mathrm{C}$ for $5^{\prime}$; then 45 cycles of denaturation of $30^{\prime \prime}$ at $95{ }^{\circ} \mathrm{C}$, annealing at $62{ }^{\circ} \mathrm{C}$ for $30^{\prime \prime}$, extension at $72{ }^{\circ} \mathrm{C}$ for $30^{\prime \prime}$ and a final extension at $72{ }^{\circ} \mathrm{C}$ for $7^{\prime}$ with a final step of $20^{\circ} \mathrm{C}$ for $1^{\prime}$. The result was visualized on a $2 \%$ agarose gel stained with SimplySafe ${ }^{\mathrm{TM}}$.

\subsubsection{Aquarium experiments for marker validation}

Marine water was obtained from a coastal site nearby (S. Juan de Nieva rocky beach, corresponding to the sampling point AV07) without any visible individual or previous record of $X$. securis and high density of other mollusks: Crassostrea gigas, Littorina littorea, Mytilus edulis, Mytilus galloprovincialis, Ostrea edulis, Ostrea stentina, Patella depressa, Patella vulgata. Small (1 L) experimental aquarium tanks were prepared adding none, one or five living $X$. securis individuals (two replicates for each density). The individuals were left in the water for $48 \mathrm{~h}$, then removed, sacrificed, and the body (without the shell) dry-weighted. The water was immediately vacuum-filtered through Supor® 200 PES Membrane Disc Filters (Pall Corporation, Life Sciences, USA) with $0.2 \mu \mathrm{m}$ pore size and $47 \mathrm{~mm}$ diameter.

\subsubsection{In situ water samples for marker validation}

Sea water was obtained from areas with or without detected presence of Xenostrobus securis (positive or negative controls respectively). As a negative control we used the site AV07, and as positive control the sites AV01, AV02 and AV05. Water samples of $1 \mathrm{~L}$ were directly taken in plastic bottles just below the surface, approx. at $1 \mathrm{~m}$ distance from the mussel bed, during low tide. They were stored in cold ice during the transport to the laboratory, where they were immediately frozen until filtering as explained above (Section 2.4.2).

\subsubsection{DNA extraction and PCR amplification from water samples}

After unfreezing the water at room temperature (or directly from aquarium experiments) DNA was extracted from the filters. Total genomic DNA was extracted using the PowerWater ${ }^{\circledR}$ DNA Isolation Kit (MOBIO Laboratories, USA) which yields high quality DNA for DNA barcoding or meta-barcoding applications. Manufacturer's instructions were followed.

PCR amplification from that DNA was performed using the primers developed here and the same conditions explained above (see Section 2.4.2). PCR products were run on $2 \%$ agarose gels stained with SimplySafe ${ }^{\mathrm{TM}}$, using EURX perfect 100-1000 bp DNA ladder for band size determination.

\subsection{Data analysis}

Correlations of mussel densities and morphometric features, and between Xenostrobus and Mytilus densities, were assessed with STATISTICA v8.0 (StatSoft, 2007). DNA sequences were visually inspected on BioEdit v7.2.5 (Hall, 1999). Every sequence was blasted against the GenBank Nucleotide database and a minimum of $98 \%$ 
nucleotide identity was set to assure the correct species identification. ClustalW (Thompson et al., 1994) application on BioEdit were employed for sequence alignment. The number of haplotypes, haplotype frequency, haplotype and nucleotide diversities with their standard deviations were calculated with DnaSp v5.10 (Librado and Rozas, 2009). Arlequin v3.11 (Excoffier and Lischer, 2010) was employed for population structure analysis. The variance within and among sampling sites in Avilés estuary were tested by applying an analysis of molecular variance (AMOVA) with 10000 permutations.
To inspect genetic differentiation between pairs of sites, pairwise $\varphi S T$ 's comparisons were done with 10000 permutations.

Additional sequences from Australia: KC509681-KC509741 (Colgan and da Costa, 2013); Vigo, Spain; Grau-du-Roi Camargue, France; Venice, Italy: FJ949108-FJ949122 (Pascual et al., 2010) and Pontevedra, Spain: JF430150-JF430154 (Guerra et al., 2013) were downloaded from GenBank to be compared with the results obtained. A sister species was also added as outgroup (Xenostrobus pulex: DQ917582). A simplified Bayesian Inference (BI) tree with 40 unique haplotypes was constructed

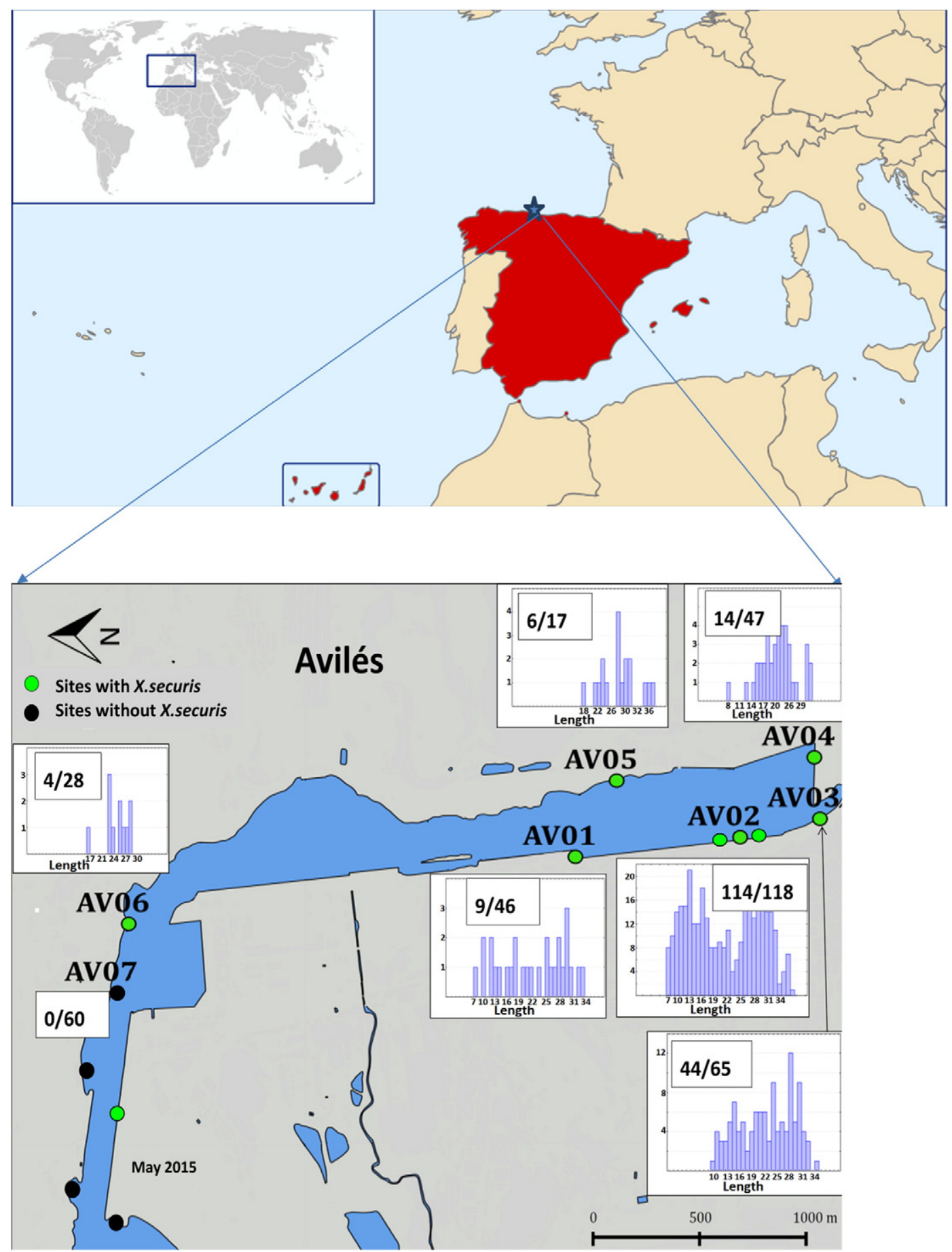

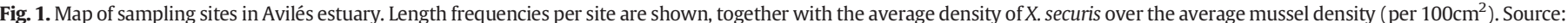

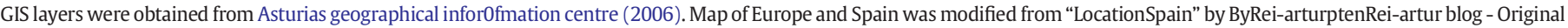

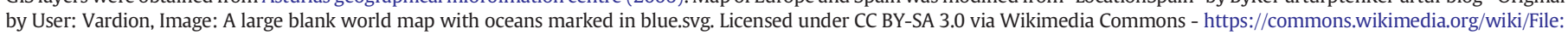
LocationSpain.svg\#/media/File:LocationSpain.svg 
in BEAST v1.8.2 (Drummond et al., 2012) for MCMC of 50 million chains, taking a sample every 1000 generations, with a tree prior model of stepwise Extended Bayesian Skyline Plot (Heled and Drummond, 2008). The substitution model was selected, based on the Bayesian inference criterion (BIC) in JModelTest v2.1.7 (Darriba et al., 2012). The mutation rate was set to $2 \%$ per million years, based on similar values for the COI gene in the Mytilidae family (Terranova et al., 2007, Lorion et al., 2012). The likelihood of the sampled trees was analysed in TRACER v1.6 (Rambaut et al., 2014). To make a consensus tree the first 5 million trees were discarded as a 'Burn-In', using Tree annotator v1.8.2 and edited in FigTree v1.4.2 (Rambaut and Drummond, 2014).

To check whether the clades found in Avilés estuary within the phylogeny were under selection or in expansion, several neutrality tests were performed. Tajima's D and Fu's Fs tests were done with Arlequin (10 000 simulations). Significant negative tests can be interpreted as a signal of population expansion. A Pearson $\chi^{2}$-test was employed to check whether the phylogenetic clades were evenly distributed over all sites.

Generally, all analyses were interpreted under a significance level of 0.05 , except the Fs-test which is conventionally tested against a significance of 0.02 .

\section{Results}

\subsection{Demographic characterisation of the exotic Xenostrobus securis population}

The survey showed that $X$. securis was present in six of the seven analysed sites (Fig. 1). Significant negative correlation between the exotic X. securis and native Mytilus spp. density was found $(\mathrm{r}=-0.49$, $\mathrm{p}=0.01$ ).

A total of 1597 individuals were measured. In the analysis only length was taken into account, due to the high correlation between the morphometric features $(r=0.96, p<0.001)$. The length frequencies of site 2 (AV02) exhibited a bimodal distribution (Fig. 1). This can be interpreted as two cohorts of recruitment. The first cohort had a mean of $10 \mathrm{~mm}$ and the second cohort of $26 \mathrm{~mm}$. The other sites were unimodally distributed, with an average length of 20-24 mm.

\subsection{Genetic barcodes}

In 130 COI sequences a total of 105 polymorphic sites were found (114 mutations). All were parsimony informative, and 27 of these changes were non-synonymous. This rendered 67 different haplotypes of 554 base pairs (GenBank accession numbers KR024822 KR024888). Levels of genetic variation, haplotype and nucleotide diversities are shown in Table 1 . At all sites the haplotype diversity was higher than $93 \%$, meaning that many sequences were single haplotypes (singletons). High nucleotide diversities were also observed. Pairwise $\varphi_{\text {ST }}$ values between sampling sites were not significant except between AV02 and AV06 ( $\left.\varphi_{\text {ST }}=0.102, p=0.026\right)$. These were respectively the sites with higher and lower density of $X$. securis.

Individuals from site 2 were combined regardless of the two length groups because an AMOVA with all groups together could not be rejected $\left(\varphi_{\text {ST }}=-0.014\right.$, p-value $\left.=0.595 \pm 0.002\right)$. Despite a clear difference in the proportion of private haplotypes among sites (Table 1), the hypothesis of a single population in the six sites sampled within Avilés Estuary could not be rejected (AMOVA with all sites, $\varphi_{\mathrm{ST}}=-0.017$, p-value $=0.202 \pm 0.001$ ).

A phylogenetic tree based on a region of 462 bp within COI Barcode (Fig. 2) shows the relationships between new and previously described haplotypes in other studies. The sequences obtained from Avilés Estuary were grouped within two main clades. One of the haplotypes (within Clade 1) was identical to other sequences obtained from native populations as well as from other European regions (nearby Galicia, France, Italy). Two sub-clades seem to occur within Clade 2, which on the other hand contains many new haplotypes from Avilés not previously reported in public databases. Haplotype and nucleotide diversities of clade 1 ( $h=0.868, \pi=0.003$ ) were clearly lower than clade $2(\mathrm{~h}=$ $0.985, \pi=0.023$ ). Clade 1 , subclade 1 and 2 respectively accounted for $21 \%, 11 \%$ and $68 \%$ of the population. The proportion of individuals of each clade was not significantly different among the considered sites ( $\chi^{2}=12.907, \mathrm{p}=0.229$ ). Significant Fu's Fs test and molecular signals of selection were found for Clade 2 (Table 2 ), which contains the most of haplotypes in the population. For the Clade 1, with less haplotypes, Tajima's D was significant, but not the rest of the tests.

\subsection{Xenostrobus securis eBarcoding}

\subsubsection{Xenostrobus securis-specific primers}

The alignment of reference sequences from GenBank allowed to identify two regions within the COI gene conserved in the analyzed and previously studied $X$. securis specimens, but different in other species. The primers designed were:

XSminiCOI-F: 5'-TCTATGGAYATRATYTTTCCTCG-3' and XSminiCOIR: 5'-GCAGTYACAGYYATAGACCA-3'.

The primers were BLASTed in silico and did not retrieve significant hits with any species except with $X$. securis COI gene sequences. These primers amplify a region of $310 \mathrm{bp}$ within COI gene.

\subsubsection{Validation in aquarium experiments}

In aquarium experiments, DNA released into the water by one individual of only $0.042 \mathrm{~g}$ in two days was detected in agarose gels filtering only $300 \mathrm{ml}$ of water (Fig. 3). Indeed the tanks containing more and/or bigger $X$. securis individuals also provided positive PCR amplicons visible in agarose gels, and this occurred in all experimental replicates. However, positive PCR amplification from experimental water samples was not found when $X$. securis was not added in the experimental tank (Fig. 3). Cross-amplification with other mollusk species present in the estuary can be discarded. The species Crassostrea gigas, Littorina littorea, Mytilus edulis, Mytilus galloprovincialis, Ostrea edulis, Ostrea stentina, Patella depressa, Patella vulgata were found in AV07 - where water for the experiment was taken from. The genetic Barcodes corresponding to these species are available in GenBank (accession numbers KJ818208KJ818238). This unambiguously confirms these species were there.

Although it cannot be considered a true quantification of PCR products, the intensity and brightness of the bands were roughly

Table 1

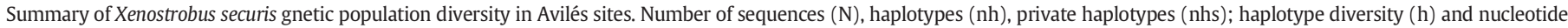
diversity $(\pi)$.

\begin{tabular}{|c|c|c|c|c|c|c|c|c|}
\hline Site & Code & Latitude & Longitude & $\mathrm{N}$ & $\mathrm{n}_{\mathrm{h}}$ & $\mathrm{n}_{\mathrm{hs}}$ & $h+$ s.d. & $\pi+$ s.d. \\
\hline Avilés 1 & AV01 & $43^{\circ} 34^{\prime} 07.99^{\prime \prime} \mathrm{N}$ & $5^{\circ} 55^{\prime} 20.39^{\prime \prime} \mathrm{W}$ & 13 & 11 & 3 & $0.974 \pm 0.039$ & $0.065 \pm 0.009$ \\
\hline Avilés 2 & AV02 & $43^{\circ} 33^{\prime} 46.07^{\prime \prime} \mathrm{N}$ & $5^{\circ} 55^{\prime} 16.42^{\prime \prime} \mathrm{W}$ & 23 & 17 & 9 & $0.986 \pm 0.005$ & $0.048 \pm 0.006$ \\
\hline Avilés 3 & AV03 & $43^{\circ} 33^{\prime} 33.32^{\prime \prime} \mathrm{N}$ & $5^{\circ} 55^{\prime} 14.37^{\prime \prime} \mathrm{W}$ & 15 & 11 & 3 & $0.933 \pm 0.054$ & $0.065 \pm 0.010$ \\
\hline Avilés 4 & AV04 & $43^{\circ} 33^{\prime} 30.61^{\prime \prime} \mathrm{N}$ & $5^{\circ} 55^{\prime} 10.83^{\prime \prime} \mathrm{W}$ & 13 & 11 & 5 & $0.974 \pm 0.039$ & $0.053 \pm 0.014$ \\
\hline Avilés 5 & AV05 & $43^{\circ} 34^{\prime} 05.58^{\prime \prime} \mathrm{N}$ & $5^{\circ} 55^{\prime} 03.67^{\prime \prime} \mathrm{W}$ & 12 & 11 & 3 & $0.985 \pm 0.010$ & $0.051 \pm 0.015$ \\
\hline Avilés 6 & AV06 & $43^{\circ} 35^{\prime} 32.38^{\prime \prime} \mathrm{N}$ & $5^{\circ} 55^{\prime} 36.57^{\prime \prime} \mathrm{W}$ & 10 & 8 & 1 & $0.933 \pm 0.010$ & $0.075 \pm 0.010$ \\
\hline Total & & & & 130 & 67 & & $0.985 \pm 0.003$ & $0.055 \pm 0.003$ \\
\hline
\end{tabular}




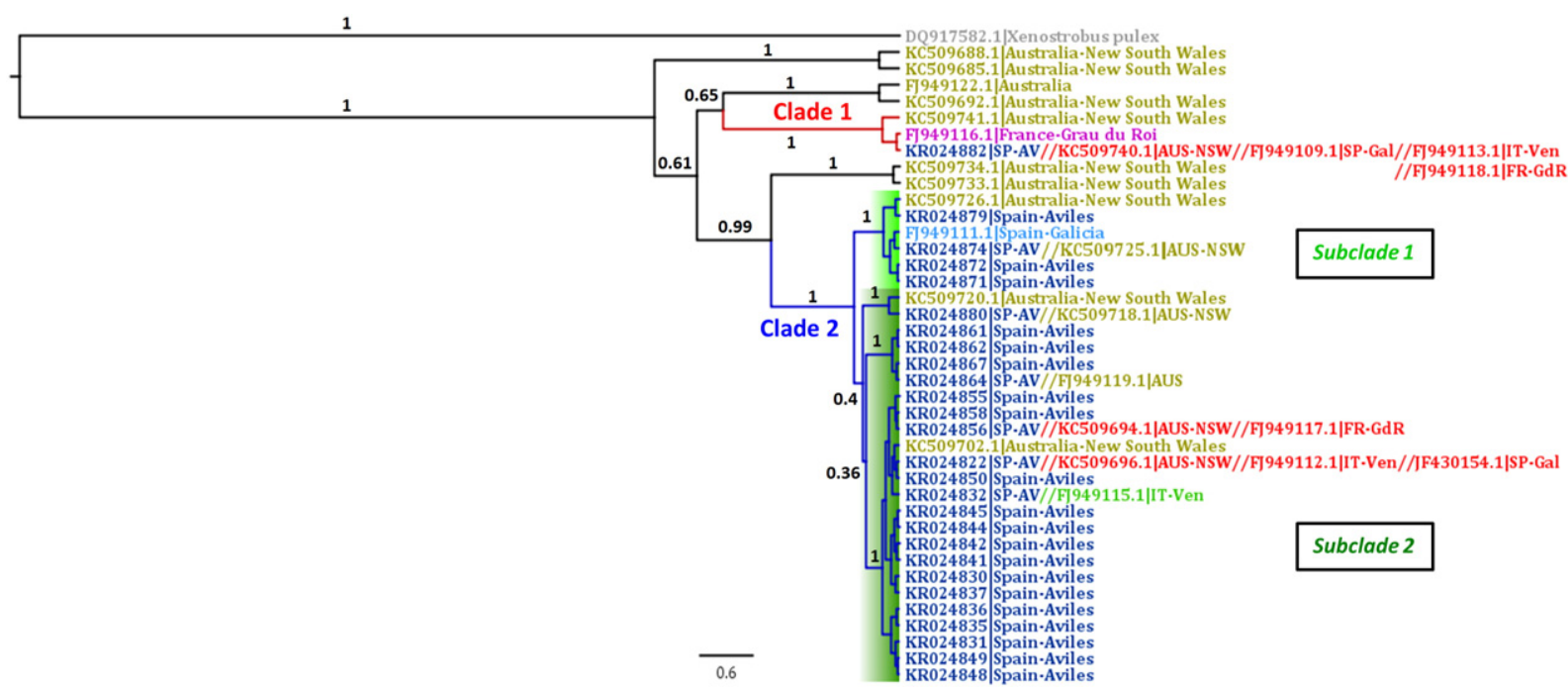

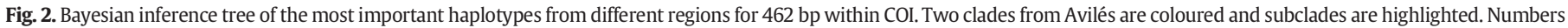
represent posterior probabilities.

proportional to the quantity of Xenostrobus (in grams) living in each experimental tank.

\subsubsection{Validation in field samples}

The utility of this specific eBarcode was confirmed from field water samples (Fig. 4). A band of the size expected for Xenostrobus securis (around $310 \mathrm{bp}$ ) was obtained from water samples from sites where the species was detected (AV01, AV02 and AV05), confirming the value of the marker for environmental monitoring purposes. In the site AV07, where no X. securis individuals were found, no amplification was detected using the newly designed species-specific primers. PCR failure with these primers was not due to poor eDNA quality since positive amplification was obtained from all assayed samples with universal primers (Geller et al., 2013) as shown in the bottom half of Fig. 4.

\section{Discussion}

This study is the first to describe a genetic marker specific of Xenostrobus securis that can be amplified directly from marine water. It joins the still short list of eDNA specific markers available for early detection of marine invaders from environmental samples, such as Asterias amenuensis (Deagle et al., 2003), Maoricolpus roseus (Gunasekera et al., 2005), Crassotrea gigas (Patil et al., 2005), Carcinus maenas (Harvey et al., 2009), Rangia cuneata (Ardura et al., 2015) and a few others. This new tool can be applied globally, since the pygmy mussel is in expansion in Asia (Morton and Leung, 2015) and Europe (Pascual et al., 2010, Adarraga and Martínez, 2012). Our results also suggest a fast expansion at small scale. The species was discovered in the harbour of Avilés (site AV02) at low frequency in 2014 (Pejović et al., 2015). The results obtained in 2015 , only one year after, support the idea of a real and fast biological invasion. Based on size distributions and high densities - especially in comparison with that of native Mytilus mussels in some sampling sites, it can be deduced that the species is already established and reproduces in the estuary. The high density and size class structure in site AV02, as well as shared haplotypes with all localities might indicate that it is likely the source of recruitment.

The rapid local expansion of the Avilés estuary population is probably enhanced by new arrivals. Multiple invasion hits could be deduced from the very high number of haplotypes found. The high haplotype and nucleotide diversities together are indicators of secondary contacts between lineages (Grant and Bowen, 1998). More private haplotypes in site AV02, the port area where the species was discovered in 2014, strongly suggests that the harbour receives multiple introductions, as repeatedly reported for marine invasions (Roman and Darling, 2007). Recurrent arrival of exotics has been also reported for other mussels (Holland, 2001, Stepien et al., 2005, Asif and Krug, 2012). High genetic variability may help these exotics to adapt and cope with environmental changes (Allendorf et al., 2012), thus allowing them to persist in the recipient ecosystem. With the present data it is not possible to know if it is a case of multiple introductions from different geographic origins, or the arrival of an already admixed population from a previously invaded location.

Overall, signals of reproduction in situ and high population densities seem to concur with similar studies (Pascual et al., 2010, Adarraga and Martínez, 2012, Iwasaki and Yamamoto, 2014). These results confirm that in the northern distribution there are no limitation on pygmy mussel's growth and reproduction. The whole estuary would be a single population, at least from the results obtained based on COI gene Barcode. The only significant pairwise difference between the possible source and the most distant site could be interpreted as a founder effect, expected at the edge of population's expansion range (site AV06 in this case if the source is AV02) (Excoffier et al., 2009, Peter and Slatkin, 2015). The high number of private haplotypes in site 2 together with signals of new recruits support this idea (Wares, 2010, Goodall-Copestake et al., 2012). Furthermore, the two invasive clades found in Avilés are consistent with the findings of Pascual et al. (2010) and Colgan and da Costa (2013). Multiple introductions may add to the range expansion of $X$. securis (Roman, 2006, Roman and Darling, 2007).

Table 2

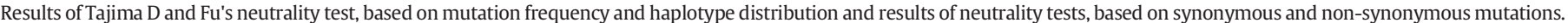

\begin{tabular}{|c|c|c|c|c|c|c|c|c|}
\hline & \multicolumn{2}{|c|}{ Tajima's D } & \multicolumn{2}{|l|}{ Fu's Fs } & \multicolumn{2}{|c|}{ HO = neutrality } & \multicolumn{2}{|c|}{ H1 = purifying selection } \\
\hline & D-value & p-value & F-value & p-value & dN-dS & p-value & dS-dN & p-value \\
\hline Clade 1 & 2.073 & 0.017 & -1.615 & 0.156 & -0.347 & 0.729 & 0.339 & 0.368 \\
\hline Clade 2 & 0.454 & 0.253 & -24.165 & 0.000 & -5.367 & 0.000 & 5.361 & 0.000 \\
\hline
\end{tabular}




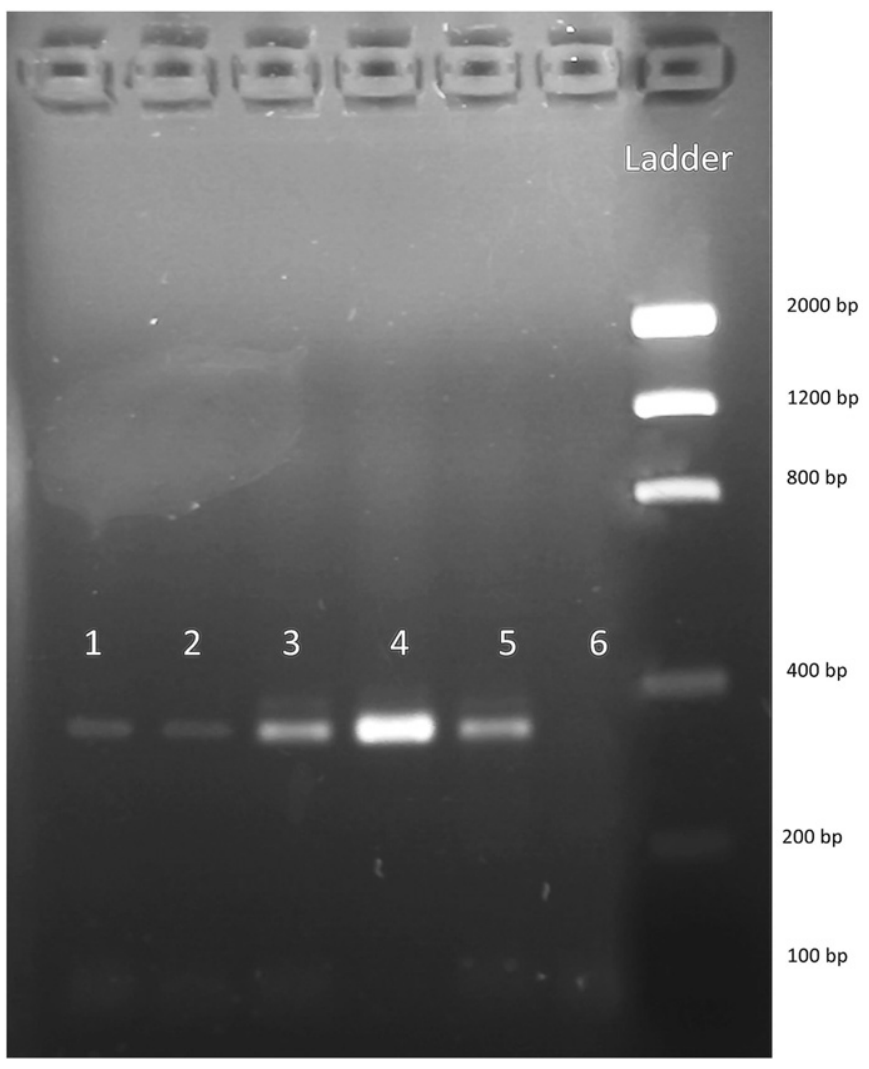

Fig. 3. Experimental validation of the eDNA marker in aquarium tanks. Agarose gel (2\%) showing PCR products obtained from amplification with XS miniCOI primers of DNA extracted from marine water with different concentrations of living Xenostrobus securis, measured as grams of fresh tissue (without shells). From left to right: $1: 0.042 \mathrm{~g} ; 2$ : $0.078 \mathrm{~g}$; 3: $0.281 \mathrm{~g}$; 4: $0.305 \mathrm{~g}$; 5: $0.368 \mathrm{~g}$; 6: 0 g (no Xenostrobus); Ladder (Low DNA Mass $^{\mathrm{TM}}$ Ladder, Invitrogen).

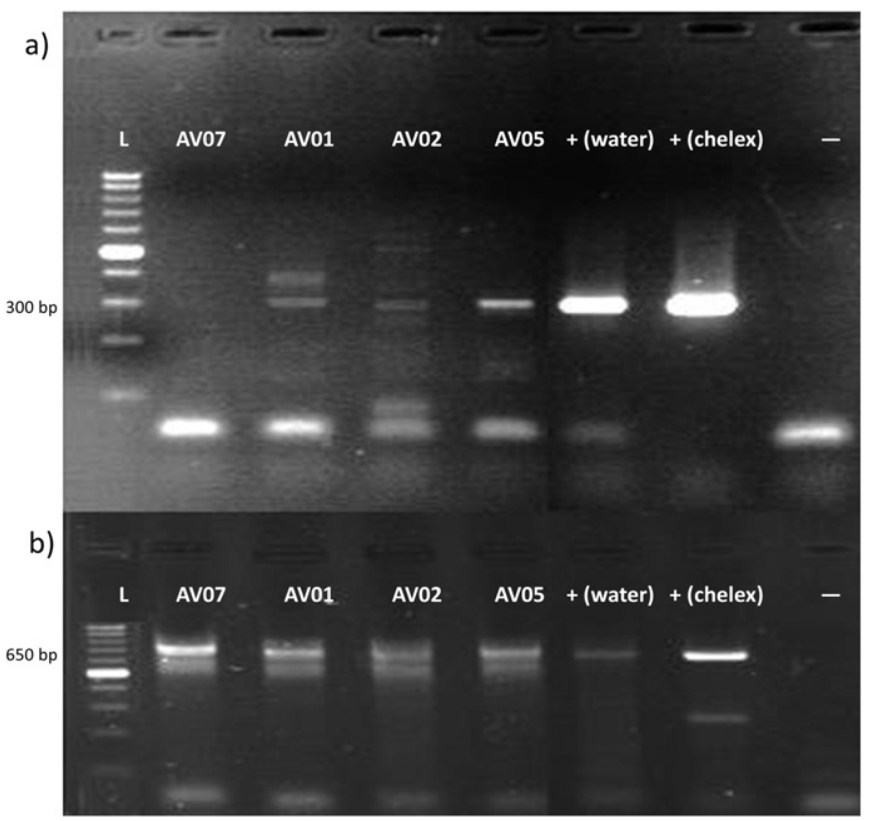

Fig. 4. In situ validation of the Xenostrobus securis eBarcoding. Agarose gel showing PCR products obtained from amplification with a) XS miniCOI primers and b) universal primers. Lane L: EURX perfect 100-1000 bp DNA ladder; Lanes AV07-AV05: water from sites 7, 1, 2 and 5 in the Avilés estuary; Lane + (water): Positive control of DNA extracted from water with $X$. securis DNA; Lane + (chelex): Positive control of DNA extracted by Chelex methodology from $X$. securis muscle tissue; Lane -: Negative control (PCR made from pure water).
The Avilés population presumably arrived through naval transport from ballast water or macrofouling. To prevent the arrival of new propagules a close examination of ships upon their arrival is necessary. The spread to other regions also needs to be prevented by careful surveillance of outgoing ships. For both purposes the Xenostrobus securis-specific marker could be used to identify larvae or adults in ballast water. Further, water quality and local diversity should be monitored, since the species could be a bio-indicator for degraded habitats. Finally, the presence of other invasive species (like X. securis) in Asturias needs to be examined by developing species-specific markers for eDNA and routine barcoding.

In conclusion, Xenostrobus securis was found in two consecutive years and the population shows evidence of multiple cohorts, meaning it survives and reproduces in the Avilés estuary. High genetic variability at the $\mathrm{COI}$ gene and two distinct clades suggest multiple introductions. Although the sources and vectors are still undetermined, there are indirect signals of arrival via shipping, since the centre of Avilés population expansion is the recreational harbour. Management of the species, focused on eradication and preventing further expansions would be recommended. Environmental surveillance is now possible directly from water samples using the Xenostrobus securis-specific marker developed in this work.

\section{Acknowledgements}

The authors would like to express their gratitude to all members of the Department of Functional Biology for their technical assistance. Also special thanks to the people of the Ecology area from the University of Oviedo for their helpful advice and use of equipment. The International Master in Marine Biodiversity and Conservation EMBC + is acknowledged by FDD for support. This work was supported by the Spanish Ministry of Economy and Competitiveness Challenge Grant MINECO CGL2013-42415-R. It is a contribution from the Marine Observatory of Asturias (OMA) and the Research Group GRUPIN14-093.

\section{References}

Abdel-Razek, F.A., Chiba, K., Kurokura, H., Okamoto, K., Hirano, R., 1993a. Distribution of Limnoperna fortunei kikuchii in shonai inlet, Lake Hamana. Suisanzoshoku 41, 89-95. Abdel-Razek, FA Chiba, K, Kurokura, H. Okamoto, K, Hirano, R, 1993b. Life history of Limnoperna fortunei kikuchii in shonai inlet, Lake Hamana. Suisanzeoshoku 41, 97-104.

Adarraga, I., Martínez, J., 2012. First record of the invasive brackish water mytilid Limnoperna securis (Lamarck, 1819) in the bay Of Biscay. Aquat. Invasions 7, 171-180.

Allendorf, F.W., Luikart, G., Aitken, S.N., 2012. Conservation and the Genetics of Populations. Wiley-Blackwell, Victoria, Australia.

Ardura, A., Zaiko, A. Martinez, J.L, Samulioviene, A. Semenova, A. Garcia-Vazquez, E. 2015. eDNA and specific primers for early detection of invasive species-A case study on the bivalve Rangia cuneata, currently spreading in Europe. Mar. Environ. Res. 112, 48-55.

Asif, J.H., Krug, P.J., 2012. Lineage distribution and barriers to gene flow among populations of the globally invasive marine mussel Musculista senhousia. Biol. Invasions $14,1431-1444$.

Asturias GPd, 2006. SITPA-IDEAS. Available at http://sitpa.cartografia.asturias.es sitpav30/pages/presentation/presentation.aspx (Accessed on 05/04/2015).

Autoridad Portuaria de Avilés, 2014. Annual report. Available at http://www. puertoaviles.es/es/autoridadportuaria/otrasinformaciones/memoriasanuales.asp (Accessed on 13/03/2015. Avilés, Spain).

Babarro, J.M.F., Lassudrie, M., 2011. Ecophysiological responses of invasive and indigenous mytilids in the Ría de Vigo (NW Spain). Aquat. Living Resour. 24, 303-315.

Bañón, R., Rolán, E., García-Tasende, M.,2008. First record of the purple dye murex Bolinus brandaris (gastropoda: muricidae) and a revised list of non native molluscs from Galician waters (Spain, NE Atlantic). Aquat. Invasions 3, 331-334.

Barbieri, M. Maltagliati, F. Di Giuseppe, G., Cossu, P., Lardicci, C., Castelli, A., 2011. New records of the pygmy mussel Xenostrobus securis (bivalvia: mytilidae) in brackishwater biotopes of the western Mediterranean provide evidence of its invasive potential. Mar. Biodivers. Rec. 4, e48.

Bishop, M., Hutchings, P., 2011. How useful are port surveys focused on target pest identification for exotic species management? Mar. Pollut. Bull. 62, 36-42.

Colgan, D.J., da Costa, P., 2013. Invasive and non-invasive lineages in Xenostrobus (bivalvia: Mytilidae). Molluscan Res. 33, 272-280.

Crocetta, F., 2011. Marine alien Mollusca in the gulf of Trieste and neighbouring areas: a critical review and state of knowledge. Acta Adriat. 52, 247-260.

Darriba, D., Taboada, G.L., Doallo, R., Posada, D., 2012. jModelTest 2: more models, new heuristics and parallel computing. Nat. Methods 9, 772. 
Deagle, B., Bax, N., Hewitt, C., Patil, J., 2003. Development and evaluation of a PCR-based test for detection of asterias (Echinodermata: asteroidea) larvae in Australian plankton samples from ballast water. Mar. Freshw. Res. 54, 709-719.

Drummond, A.J., Suchard, M.A., Xie, D., Rambaut, A., 2012. Bayesian phylogenetics with BEAUti and the BEAST 1.7. Mol. Biol. Evol. 29, 1969-1973.

Estoup, A., Largiader, C., Perrot, E., Chourrout, D., 1996. Rapid one-tube DNA extraction for reliable PCR detection of fish polymorphic markers and transgenes. Mol. Mar. Biol. Biotechnol. 295-298.

Excoffier, L., Lischer, H.E., 2010. Arlequin suite ver 3.5: a new series of programs to perform population genetics analyses under Linux and windows. Mol. Ecol. Resour. 10, 564-567.

Excoffier, L., Foll, M., Petit, R.J., 2009. Genetic consequences of range expansions. Annu. Rev. Ecol. Evol. Syst. 40, 481-501.

Flor, G., Jd, Busto, Blanco, G.F., 2006. Morphological and sedimentary patterns of ports of the asturian region (NW Spain). J. Coast. Res. 35-40.

Garci, M.E., Trigo, J.E., Pascual, S., González, A.F., Rocha, F., Guerra, A., 2007. Xenostrobus securis (Lamarck, 1819) (Mollusca: bivalvia): first report of an introduced species in Galician waters. Aquac. Int. 15, 19-24.

Geller, J.B., Darling, J.A., Carlton, J.T., 2010. Genetic perspectives on marine biological invasions. Ann. Rev. Mar. Sci. 2, 367-393.

Geller, J., Meyer, C., Parker, M., Hawk, H., 2013. Redesign of PCR primers for mitochondrial cytochrome c oxidase subunit I for marine invertebrates and application in all-taxa biotic surveys. Mol. Ecol. Resour. 13, 851-861.

Giusti, F., Dell Angelo, B., Sosso, M., Schiaparelli, S., 2008. First record of the invasive species Xenostrobus securis (Lamarck, 1819)(bivalvia: mytilidae) from Central Tyrrhenian Sea (Western Mediterranean). Boll. Malacol. 44, 11.

Goodall-Copestake, W., Tarling, G., Murphy, E., 2012. On the comparison of populationlevel estimates of haplotype and nucleotide diversity: a case study using the gene cox1 in animals. Heredity 109, 50-56.

Grant, W., Bowen, B., 1998. Shallow population histories in deep evolutionary lineages of marine fishes: insights from sardines and anchovies and lessons for conservation. J. Hered. 89, 415-426.

Guerra, Á., Pascual, S., Garci, M.E., Roura, Á., Mucientes, G., González, Á.F., 2013. The blackpygmy mussel Limnoperna securis in Galician rias (north-eastern Atlantic): new records and first evidence of larval stages predation by copepods. Mar. Biodivers. Rec. 6, 1-7.

Gunasekera, R.M., Patil, J.G., McEnnulty, F.R., Bax, N.J., 2005. Specific amplification of mtCOI gene of the invasive gastropod Maoricolpus roseus in planktonic samples reveals a free-living larval life-history stage. Mar. Freshw. Res. 56, 901-912.

Hall, T.A., 1999. BioEdit: a user-friendly biological sequence alignment editor and analysis program for windows 95/98/NT. Nucleic Acids Symp. Ser. 41, 95-98.

Harvey, J.B., Hoy, M.S., Rodriguez, R.J., 2009. Molecular detection of native and invasive marine invertebrate larvae present in ballast and open water environmental samples collected in Puget Sound. J. Exp. Mar. Biol. Ecol. 369, 93-99.

Heled, J., Drummond, A.J., 2008. Bayesian inference of population size history from multiple loci. BMC Evol. Biol. 8, 289.

Holland, B.S., 2001. Invasion without a bottleneck: microsatellite variation in natural and invasive populations of the brown mussel Perna perna (L). Mar. Biotechnol. 3, 407-415.

Hoos, P.M., Whitman Miller, A, Ruiz, G.M., Vrijenhoek, R.C., Geller, J.B., 2010. Genetic and historical evidence disagree on likely sources of the Atlantic amethyst gem clam Gemma gemma (Totten, 1834) in California. Divers. Distrib. 16, 582-592.

Iwasaki, K., 2006. Human-Mediated Introduction of Marine Organisms in Japan: a Review. In: Koike, F., Clout, M.N., Kawamichi, M., De Poorter, M., Iwatsuki, K. (Eds.) Assessment and Control of Biological Invasion Risks. IUCN Publications Services, Gland, Switzerland.

Iwasaki, K., Yamamoto, H. 2014. Recruitment and population structure of the nonindigenous brackish-water mytilid Xenostrobus securis (lamark, 1819) in the Kino River, Japan. Aquat. Invasions 9, 479-487.

Katsanevakis, S., Gatto, F., Zenetos, A., Cardoso, A.C., 2013. How many marine aliens in Europe. Manag. Biol. Invasion. 4, 37-42.

Kimura, T., Sekiguchi, H., 2009. Spatial and temporal patterns of abundance of the exotic mytilid Xenostrobus securis and the native mytilid Musculista senhousia in the Lake Hamana, Japan. Mar. Biodivers. Rec. 2, 1-7.

Kimura, T., Tabe, M., Shikano, Y., 1999. Limnoperna fortunei kikuchii habe, 1981 (bivalvia: mytilidae) is a synonym of Xenostrobus securis (Lamarck, 1819): introduction into Japan from Australia and/or New Zealand. VENUS: Jpn. J. Malacol. 58, 101-117.

Kohama, T., Montani, S., Kajiwara, Y., Yamada, M., 2001. Population dynamics of sessile bivalves Mytilus galloprovincialis and Xenostrobus securis in hyper Eutrophicated Bay, Japan. Bull. Jpn. Soc. Sci. Fish. 67, 664-671.
Lazzari, G., Rinaldi, E., 1994. Alcune considerazioni sulla presenza di specie extra mediterranee nelle lagune salmastre di Ravenna. Boll. Malacol. 30, 195-202.

Librado, P., Rozas, J., 2009. DnaSP v5: A software for comprehensive analysis of DNA polymorphism data. Bioinformatics 25, 1451-1452.

Lorion, J., Halary, S., Do Nasciment, J., Samadi, S., Couloux, A., Duperron, S., 2012. Evolutionary history of Idas sp. Med (Bivalvia: Mytilidae), a cold seep mussel bearing multiple symbionts. Cah. Biol. Mar. 53, 77-87.

McDonald, J., Koehn, R., 1988. The mussels Mytilus galloprovincialis and M. trossulus on the Pacific coast of North America. Mar. Biol. 99, 111-118.

Morton, B., Leung, K., 2015. Introduction of the alien Xenostrobus securis (bivalvia: mytilidae) into Hong Kong, China: interactions with and impacts upon native species and the earlier introduced Mytilopsis sallei (bivalvia: dreissenidae). Mar. Pollut. Bull. 92, 134-142

Pascual, S., Villalba, A., Abollo, E., Garci, M., González, A.F., Nombela, M., Posada, D., Guerra, A., 2010. The mussel Xenostrobus securis: a well-established alien invader in the ria de Vigo (Spain, NE Atlantic). Biol. Invasions 12, 2091-2103.

Patil, J.G., Gunasekera, R.M., Deagle, B.E., Bax, N.J., 2005. Specific detection of Pacific oyster (Crassostrea gigas) larvae in plankton samples using nested polymerase chain reaction. Mar. Biotechnol. (NY) 7, 11-20.

Pejović, I., Ardura, A., Miralles, L., Arias, A., Borrell, Y.J., Garcia-Vazquez, E., 2015. DNA Barcoding for Assessment of Exotic Molluscs Associated with Maritime Ports in Northern Iberia Marine Biology Research.

Perrings, C., Williamson, M., Barbier, E.B., Delfino, D., Dalmazzone, S., Shogren, J., Simmons, P., Watkinson, A., 2002. Biological invasion risks and the public good: an economic perspective. Conserv. Ecol. 6, 1-7.

Peter, B.M., Slatkin, M., 2015. The effective founder effect in a spatially expanding population. Evolution 69, 721-734.

Rambaut, A., Drummond, A., 2014. FigTree. Version 1.4. Available at: http://acuk/ software/figtree/ (Accessed on 25/03/2015).

Rambaut, A., Suchard, M., Xie, D., Drummond, A., 2014. Tracer v1. 6. Available at: http:// beastbioedacuk/Tracer (Accessed on 25/03/2015).

Rilov, G., Crooks, J.A., 2009. Biological Invasions in Marine Ecosystems: Ecological, Management, and Geographic Perspectives vol. 204. Springer, Berlin, Germany.

Roman, J., 2006. Diluting the founder effect: cryptic invasions expand a marine invader's range. Proc. R. Soc. B Biol. Sci. 273, 2453-2459.

Roman, J., Darling, J.A., 2007. Paradox lost: genetic diversity and the success of aquatic invasions. Trends Ecol. Evol. 22, 454-464.

Sabelli, B., Speranza, S., 1994. Rinvenimento di Xenostrobus sp.(bivalvia: mytilidae) nella laguna di venezia. Boll Malacol 29, 311-318.

StatSoft, I., 2007. In: StatSoft I (Ed.), STATISTICA (data analysis software system), version 8.0 (Availible at www.statsoft.com).

Stepien, C.A., Brown, J.E., Neilson, M.E., Tumeo, M.A., 2005. Genetic diversity of invasive species in the Great Lakes versus their Eurasian source populations: insights for risk analysis. Risk Anal. 25, 1043-1060.

Terranova, M., Lo Brutto, S., Arculeo, M., Mitton, J., 2007. A mitochondrial phylogeography of Brachidontes variabilis (bivalvia: mytilidae) reveals three cryptic species. J. Zool. Syst. Evol. Res. 45, 289-298.

Thompson, J.D., Higgins, D.G., Gibson, T.J., 1994. CLUSTAL W: improving the sensitivity of progressive multiple sequence alignment through sequence weighting, positionspecific gap penalties and weight matrix choice. Nucleic Acids Res. 22, 4673-4680.

Wares, J.P., 2010. Natural distributions of mitochondrial sequence diversity support new null hypotheses. Evolution 64, 1136-1142.

Wilson, B.R., 1968. Survival and reproduction of the mussel Xenostrobus securis (lam.) (Mollusca: bivalvia: mytilidae) in a Western Australian estuary: Pt. I salinity tolerance. J. Nat. Hist. 2, 307-328

Wilson, B.R., 1969. Survival and reproduction of the mussel Xenostrobus securis (Lamarck) (Mollusca; bivalvia; mytilidae) in a Western Australian estuary. Pt. II: reproduction, growth and longevity. J. Nat. Hist. 3, 93-120.

Wilson, B.R., Hodgkin, E., 1967. A comparative account of the reproductive cycles of five species of marine mussels (bivalvia: mytilidae) in the vicinity of Fremantle, Western Australia. Aust. J. Mar. Freshwat. Res. 18, 175-203.

Zaiko, A., Martinez, J.L., Schmidt-Petersen, J., Ribicic, D., Samuiloviene, A., Garcia-Vazquez, E., 2015a. Metabarcoding approach for the ballast water surveillance-An advantageous solution or an awkward challenge? Mar. Pollut. Bull. 92, 25-34.

Zaiko, A., Samuiloviene, A., Ardura, A., Garcia-Vazquez, E., 2015b. Metabarcoding approach for nonindigenous species surveillance in marine coastal waters. Mar. Pollut. Bull. 100, 53-59. 